\title{
Valency Patterns in Indonesian
}

\author{
Ketut Artawa, Udayana University \\ Made Sri Satyawati, Udayana University \\ Ketut Widya Purnawati, Udayana University
}

\begin{abstract}
Every language has a verb category. Verbs can be classified in a number of different ways. For this study, the classification used is based on the number of the elements needed by a certain verb in order to build a grammatical sentence. The element which is required by a verb is termed valency. The verbs Indonesian are generally classified into: affixless and affixed verbs. For the affixed verbs, the base form can be: adjectives, nouns, 'precategorials' or even verbs. The focus of this study is to discuss valency patterns and their alternations in Indonesian using a list of 70 meanings proposed by Malchukov and Comrie (2010). The result of the study showed that the attachment of the suffix $-i$ and $-k a n$ to the base form mostly produced locative-causative pattern alternations. The result of this study is relevant not only to the understanding of the theoretical aspects of the valency alternation, but it is also useful as the theoretical basis for compiling valency dictionary for Indonesian.
\end{abstract}

Keywords: causative; locative; valency; valency pattern; verb

\section{Introduction}

In general verbs can be distinguished into: intransitive, transitive, and ditransitive verb. In some languages the transitive verbs may be used intransitively. This kind of verb is often called semi-transitive verb or ambitransitive verb. Verbs in Indonesian can be basic (affixless verb) and derived (affixed verb). Indonesian is morphologically an agglutinative language. It has a number of affixes that can be used to derive verbs from different word classes. The intransitive verb is formed by the prefix ber- and meng-, as in berbaring 'lie down', menari 'dance' or it can be in its base form as in tidur 'sleep', mandi 'take a bath'. A transitive verb can be in its base form as in pukul 'hit', bawa 'bring' or it can also be a derived form as in lemparkan 'throw', bersihkan 'clean'. Transitive verbs are inflected for voice; meng- marks active voice, $d i$-marks passive voice.

The verbal affixation in Indonesian has attracted a number of researchers and will always be a challenging topic for further research. The data of the Indonesian verbs used in this study were gathered using the database questionnaire developed for the Leipzig Valency Classes Project by Andrej Malchukov and Bernard Comrie (2010). This questionnaire has been used to gather data cross-linguistically. Balinese is one of the languages included in this project (Shibatani \& Artawa, 2015). The result of the project on Balinese valency classes is published as one of the articles in the handbook of Valency Classes in the World's Languages (2015) edited by Malchukov and Comrie. The questionnaire has 70 verbs meanings and each of them has a role frame and typical context. By filling this questionnaire, the basic valency patterns or alternations can be identified, classified and analysed.

\section{Verbal morphology and clause structure}

In relation to verb category, Indonesian has a number of affixes that can be used to form verb from different base categories. The intransitive verb in Indonesian can be distinguished into basic and the derived verb form. An important point that needs to be mentioned for the verb morphology in Indonesian is the nature of the base. The base can be ditinguished into: a free base and a bound base (root). This root form is often referred to as a precategorial. This term is used to refer to a base form whose category cannot be determined yet so it cannot be used in syntax. Thus, this precategorial base always occurs with affixation. Take for example the form alir 'flow', it must take a prefix, meng-, or a suffix, $-i$ or -kan in order to function syntactically. 
Underived verb

(1) * Dia alir air ke sawah
I flow water to rice-field
'I am flooding the rice field with water

meng-derived verb

(2) Air meng-alir ke sawah

Water flow to rice-field

'The water is flowing to the rice-field'

$-i$ derived verb

$\begin{array}{ccll}\text { (3) Saya mengalir-i } & \text { sawah dengan } & \text { air } \\ \text { I flow } & \text { rice-field with } & \text { water } \\ \text { 'I am flooding the rice-field with water' } & \end{array}$

-kan derived verb

(4) Saya mengalir-kan air ke sawah

I flow water to rice-filed

'I caused the water to flow to the rice field

The clause structures are distinguished into three: the agentive voice (AV) in which the verb is marked by meng-, the objective voice (OV) in which the verb is unmarked or occurs in its basic form, and passive voice (PASS) in which the verb is marked by the prefix $d i$-.

\section{Analysis}

By applying the perceptual construct of the figure-ground distinction that has been proposed by a number of linguists in their descriptions of the argument realization in several languages (Talmy, 2000 \& Croft, 1991), the alternation of the possible valency patterns can be clearly discussed. According to Shibatani and Artawa (2015), this approach has been applied to Balinese. In terms of the thematic roles, the Theme corresponds to the Figure and represents an entity that is situated at a location or that moves from one location to another in physical space or from one state to another in the construal of a change-of-state as an abstract motion. The Ground is background against which a figure is delineated and corresponds to various locative expressions in language ranging over a stationary location, a source location, a goal location, etc. with respect of which the Theme expression is predicated as being located or moving. Locations can be both physical or human, and thus both so-called goal location (as in John walked to the station) and human recipient (as in John gave Bill the book) count as instances of the Ground. The widely recognized semantic role of Patient is construed as an instance of the Ground in this paper as in (5) below.

(5)

GR=Object construction

a. John loaded the wagon with hay.

b. John hit the fence with the stick.

(6) FIG=Object construction

a. John loaded the hay onto the wagon.

b. John hit the stick against the fence.

In relation to this alignment, Indonesian shows that $-i$ derived forms align a Ground expression with the Object as shown in the following examples. 
(7)

a. Dia tidur di kamar baru-nya.

he sleep at room new-3SG.POSS

'He slept in his new room.'

b. Dia men-tidur-i kamar baru-nya.

he AV.sleep-LOC room new=3SG.POSS

'He slept in his new room.'

(8) a. Saya menanam pisang di ladang.

I AV.plan banana in garden

'I planted bananas in the garden.'

b. Saya menanam-i ladang (dengan) pisang.

I AV.plant-LOC garden (with) banana

'I planted the garden with bananas.'

Contrary to the $-i$ derivation that aligns a Ground expression with the Object, the -kan derivation aligns a Figure expression with the Object. There are two types of Figure involved in this derivation. The typical causative construction aligns with the Object, the Theme Figure of a caused motion as in I pushed the chair across the room and I made himroll down the hill. The other type of Figure involved here is an instrument that moves and typically comes into contact with a Ground element. Indonesian treats these two types of Figure together and aligns both of them with the Object by the use of the -kan suffix. In other words, this suffix unifies the causative and the instrumental applicative construction.

a. Anak itu naik ke truk itu

Person that AV.climb to truck that

'The child climbed onto the truck.'

b. Dia menaik-kan anak itu ke truk itu

s/he AV.climb-CAUS child that to truck that

'He loaded the child onto the truck/ Lit. He made the child climb onto the truck.'

(10) a. Dia mencium adik=nya

s/he AV.kiss younger.sibling=3.POSS

'S/he kissed his/her younger sibling.'

b. Saya mencium-kan dia pada adik-nya

I AV.kiss-CAUS s/he to younger.sibling=3.POSS

'I made him/her kiss his/her younger sibling.'

When -kan derives a causative from an action verb, the meaning associated with it is that of associative causation including the assistive and join-action subtypes. Sentence (10b), for example, means either forcing him/her to kiss the younger sibling by moving his/her head close to his/her younger brother/sister, or assisting him/her to kiss the younger sibling by allowing him/her come closer to his/her younger brother/sister

Morphological causatives with -kan also derive causative transitive's from stative predicates, as in the following examples. The Figure status of the cause in these cases is abstractly construed as a Theme moving from one state to another.
a. Rumah itu bersih.
House that clean
'The house is clean.' 
b. Saya membersih-kan rumah itu

I AV-clean-CAUS house that

'I cleaned the house'

The following illustrates the typical use of -kan aligning an instrumental expression with the Object.

$\begin{array}{clll}\text { a. (Dia) memukul anjing } & \text { itu dengan sapu. } \\ \text { s/he AV-hit } & \text { dog } & \text { that with broom }\end{array}$

'S/he hit the dog with a broom.

b. Dia memukul-kan sapu itu ke anjing itu

s/he AV-hit-CAUS bloom that to dog that

'S/he hit a broom against the dog.'

The above use of -kan would normally be analyzed as a case of instrumental applicative. However, comparing the alignment patterns of this instrumental applicative in (12b) with the following causative pattern, it shows that in both the Figure expressions are aligned with the object and the Ground expressions are coded as a prepositional phrase. The example in (14) is a derived locative construction, which shows that Ground is the object.

FIG=OBJ alignment (-kan causative suffix)

$\begin{array}{llllll}\text { Saya mengajar-kan } & \text { bahasa } & \text { Inggris } & \text { kepada } & \text { anak-anak } & \text { itu. } \\ \text { I } & \text { AV-teach-CAUS language } & \text { English } & \text { to } & \text { person } & \text { that } \\ \text { 'I teach the English language (to children).' } & & & \end{array}$

GR=OBJ alignment $(-i$ locative suffix $)$
Saya mengajar-i $\quad$ anak-anak itu bahasa
I Inggris
'I teach the children (the English language).

Instrumental applicative in Indonesian are apparently construed as a case of caused motion, where an instrument moves in space and comes to contact with a Ground where the action denoted by the verb culminates. That is, the -kan construction represents a conceptualization of a situation as a caused motion, which involves both a Theme Figure and a location Ground to which the former moves. Verb classes and their potential alignment patterns can be summarized in the following table.

Table 1: Verb classes and their potential alignment

\begin{tabular}{|l|c|c|}
\hline \multicolumn{1}{|c|}{ Alignment } & $\begin{array}{c}\text { GR=OBJ }>\text { FIG=OBL/OBJ } \\
\text { (Locative pattern) }\end{array}$ & $\begin{array}{c}\text { FIG=OBJ }>\text { GR=OBL } \\
\text { (Causative pattern) }\end{array}$ \\
\hline Basic verb class (A) & Basic form & $-k a n$ form \\
\hline Basic verb class (B) & $-i$ form & Basic form \\
\hline Basic verb class (C) & $*_{-i \text { form }}$ & Basic form \\
\hline Basic verb class (D) & $\begin{array}{c}\text { Basic form } \\
-i \text { form }\end{array}$ & $\begin{array}{c}-k a n \text { form } \\
\text { Basic form }\end{array}$ \\
\hline Precategorial verbs & $-i$ form & $-k a n$ form \\
\hline
\end{tabular}


Basic verb class (A) includes those underived verbs that exhibit the two alignment patterns without derivation. Basic verb class (B) has verbs whose basic forms have the GR=OBJ pattern, and derived -kan forms the $\mathrm{FIG}=\mathrm{OBJ}$ pattern, while basic verb class $(\mathrm{C})$ reverses the derivation pattern such that the basic forms show the $\mathrm{FIG}=\mathrm{OBJ}$ pattern and derived $-i$ forms the $\mathrm{GR}=\mathrm{OBJ}$ pattern. There is, in addition, a group of verbs (D) whose basic valency patterns conform either to that of the $-i$ derived forms or the $-k a n$ derived forms, with their derived partners showing the other pattern.

\section{Conclusion}

The locative $-i$ and causative - $k a n$ suffixes play an integral role in the valency structures of Indonesian verbs making it impractical to separate the valency patterns associated with underived basic verbs and those displayed by the derived forms of so-called precategorial verbs without inherent valency value. Indeed the precategorial/non-precategorial distinction has an important implication to the study of the valency pattern. When semantically bi-/trivalent verbs are precategorial, they typically allow both $-i$ and $-k a n$ derivations and their attendant alignment patterns. However, when verbs are non-precategorial, the basic, non-derived forms typically represent the alignment pattern of either $-i$ or -kan derived forms; hence they typically have only one derivation either in $-i$ or $-k a n$.

\section{References}

Croft, W. 1991. Syntactic categories and grammatical relations: the cognitive organization of information. Chicago: University of Chicago Press.

The Leipzig Valency Classes Project's Database Questionnaire Manual. Available at http://valpal.info/public/valencydbquestionnairemanual.pdf . (Accessed on May 6, 2018)

Shibatani, M., \& Pardeshi, P. 2002. The causative continuum. In Shibatani, M (ed.). The Grammar of Causation and Interpersonal Manipulation. Amsterdam: John Benjamins. 85-126.

Shibatani, Masayoshi \& Artawa, Ketut. 2015. Balinese Valency Classes. In Malchukov, A \& Comrie, B (ed.). Valency Classes in the World's Languages. Berlin: Mouton De Gruyter, $877-940$

Sneddon, J. 1996. Indonesian reference grammar. London, New York: Routledge.

Talmy, Leonard. 2000. Toward a cognitive semantics. Cambridge, Mass.: MIT Press. 